\title{
THE BULGARIAN DEFENCE TECHNOLOGICAL AND INDUSTRIAL BASE AND THE NATIONAL SECURITY OF BULGARIA
}

\author{
Ivaylo Ivanov ${ }^{1}$
}

DOI: https://doi.org/10.31410/LIMEN.2019.43

\begin{abstract}
The scale of production and export of defence-related and special production from Bulgaria has increased steadily over recent years. The Export of this group of goods is expected to exceed the value of $€ 1$ billion at the end of 2019. The Bulgarian Defence Technological and Industrial Base (BDTIB) is making a significant contribution to this process. The purpose of the author is to present summarized results of an analysis of the challenges to the functioning and development of this important for the Bulgarian economy industrial sector. From a practical point of view, the results of the analysis would be particularly useful for decision-makers in the sector at the state and company level, researchers and other stakeholders. Significant opportunities and risks to the BDTIB have also been outlined in two main directions. The first one is related to the current situation on the specific and highly competitive international markets for defence goods and services defined as very dynamic and rapidly changing. Bulgarian enterprises are forced to actively compete for their presence in these markets without any state support. The second challenge ahead of BDTIB is the dismal results of the overall process of modernizing the Bulgarian security sector. BDTIB continues to seek its adequate role in the national modernization projects for the Bulgarian Armed Forces and Ministry of Interior of the Republic of Bulgaria. For all these reasons, the results of BDTIB's activities in recent years have contributed indirectly to Bulgaria's national security.
\end{abstract}

Keywords: Bulgaria, Economic development, Defence-related and special production export, National modernization projects, Bulgarian Defence Industry Association.

\section{INTRODUCTION}

$\mathrm{D}$ uring the 1990s the need for transforming the existing socio-economic system in Bulgaria slowly but surely became clear for everyone. The economic transformation as an absolute necessity was the only chance for the country to exit the permanent crises after the end of the planned economy in 1989. The chosen approach for national economic transformation was a liberal market economy. Privatization and most of the structural reforms were implemented effectively but not efficiently. The contemporary development course of the Bulgarian economy is predetermined by the lack of holistic vision and strategy of the transition measures design and implementation. During the transition period, the Bulgarian industry as a whole and its defence sub-sectors were also dramatically affected by a change of the ownership and transformed to some extent.

There are lots of basic problems that represent obstacles for the up-to-date development of local Bulgarian defence and technological industrial base. One of the aims of the present article is not only revealing that problems, but outlining the horizon ahead of this important industrial sector for the Bulgarian economy, too. This is important as this sector has a chance again to be an engine for the whole industrial business development in the country, especially in the background of the integration processes and defence cooperation across Europe. Additionally, the industry's direct influence on some of the aspects of national security has to be explored and revealed.

1 University of National and World Economy - Sofia, Studentski grad, "8-mi dekemvri" blvd., 1700 Sofia, Bulgaria 


\section{A TERMINOLOGICAL CLARIFICATION - THE DEFENCE INDUSTRY VS THE DEFENCE TECHNOLOGICAL AND INDUSTRIAL BASE}

One terminological clarification is needed. In the present paper, the term "Defence Technological and Industrial Base (DTIB)"2 is used predominantly. The unprejudiced reader has to know that DTIB is a more complex and comprehensive term than classical examples like Military-Industrial Complex (MIC) and Defence industry etc. DTIB may include all the industries in which products and services are at disposal not only at defence needs but mainly for security ones. The DTIB appearance in the theory and the practice is a result of the enormous transformations in the defence industries, started at the end of the 1980s, and accelerated sharply in the 1990s. These transformations are determined by the fundamental changes in the international military-political situation, military-technical and economic factors. From the historical point of view in the present paper, the term Bulgarian military-industrial complex (BMIC) ${ }^{3}$ is also used.

The changes in the defence industries sector across the European Union (EU) impose this new philosophy in Bulgarian practice, too. The main activities are oriented to restructuring and development of competitive defence industries in the EU framework, an integrated European market for defence products, and consolidation of a robust European Defence Technological and Industrial Base (EDTIB) (Need for a European defence industry: industrial, innovative and social aspects 2012). The maintenance of a strong and competitive DTIB in Europe is a fundamental underpinning of the European Security and Defence Policy (Strategy for the European Defence Technological and Industrial Base, 2007). The European Defence Fund announced by President Juncker in September 2016 (State of the Union Address, 2016), and backed by the European Council in December 2016, is already a fact (European Commission - Press release, 2017). That ambitious European Defence Fund will contribute to a European Union that protects and defends its citizens, complementing other ongoing work strands, namely the Global Strategy's Implementation Plan on Security and Defence, which sets out a new level of ambition for the Union and identifies actions to fulfil it, as well as with the implementation of the EU-NATO Joint Declaration signed by the President of the European Council, the President of the Commission and the Secretary-General of NATO. It is too early to determine the effects of the Fund but its influence over the defence industry sector in the EU is inevitable.

\section{WORLD TENDENCIES IN DEFENCE TECHNOLOGICAL AND INDUSTRIAL BASE DEVELOPMENT}

After the end of the Cold war, an intensive and deep reorganization of so-called "military sectors" of all economies followed. The structural changes in the economy could be described with new ratios between the military and civil production. The military/defence sectors of the economy are reorganized in a course of convergence between defence and civil production. This process is based on flexible dual-use technologies.

As a whole, the defence industrial transformation processes at the end of the $\mathrm{XX}$ and the beginning of the XXI century are in the general trend of the industry and technology development. The new challenges of the environment - terrorism and the other asymmetric threats caused

Defence Technological and Industrial Base (DTIB) - Industrial assets that are of direct or indirect importance for the production of equipment for a country's armed forces.

3 Bulgarian military-industrial complex (BMIC) - The existing technology and production structure of the Bulgarian defence industry during the Cold war 
brand-new needs. The demand for goods and services from the defence industry has changed. The new challenges have led to defence strategy transformation of most of the countries - from preparation policy based on the struggle against a distinctive enemy to policy based on capabilities' development for coping with the threats of the present-day.

The result of that serious transformation affected significantly the international defence economic relations. The difference lies in the refusal of one national R\&D and production model of modern armaments and equipment. The globalized defence industry is acquiring a clear form of firm's nets with distinct strategic centres.

These conditions leave their stamp on the development of the nowadays DTIB in each level global, regional and national. Meanwhile, the BDTIB lags significantly from this trend.

\section{THE BMIC - SHORT HISTORY}

The fundamentals of the present Bulgarian defence industry (BMIC) were put in place in the late 1960s and throughout the 1970s when dozens of enterprises were built and modernized with significant Soviet help. During the socialist period, the BMIC consisted of three main groups of enterprises (Ivanov, 1998, p. 95). The production capabilities were of a combined-type, with a technological division of labour. The production process was designed for mass production with high levels of technological specialization. Defence production was a state monopoly as the enterprises were fully state-owned, with very high centralization of the overall management, including planning, investment, a supply of raw materials and production equipment and trade realization of the production. The production cycle started with centralized planning and financing of R\&D and all necessary patents and licenses for production. All of this was established in the frameworks of the Council for Mutual Economic Assistance (COMECON) and subordinated to the strategic needs of the Warsaw Pact (WP) (Dimitrov 2002, pp 10-16).

A highly specialized production base in metal-working, machine-building, and electronics have been developed. This specialization included SALW (Small Arms and Light Weapons), armoured vehicles, and electronics (Dimitrov 2002, p. 13). During the socialist period, the BMIC was characterized by a clear focus on the manufacture for export (about 90 percent of its output), advanced production technology and efficient production structure. Its product range was oriented towards market niches and Bulgaria's specialization within the WP (Dimitrov and Ivanov 1993, p 94). Bulgaria supplied arms to countries from the WP, the Middle East, North Africa, India and other smaller markets (Brauer and van Tuyil 1996, p 128.) A relatively large share, between 30 and 40 percent of the exports, depended on the political relations that Bulgaria had with these partner countries. This trade was worth several hundred million US dollars per year.

The collapse. The political changes at the end of the 1980s and the beginning of the 1990s, the breaking up of the WP, the disintegration of COMECON brought with them lots of common and special economic problems for BMIC. According to the Weapons Under Scrutiny Report (Bulgarian Center for Study of Democracy, 2004) the difficult process of transition to democracy and a market economy, characterized by a financial and economic crisis, a weakening of state control, and political instability, had a huge impact on the Bulgarian defence industry. Bulgaria's traditional export markets declined rapidly; for several reasons. Firstly, on a global level, increased demand for modern armaments hurt exports of some of Bulgaria's relatively low-tech items such as SALW. Secondly, increased export control measures, at the national and interna- 
tional level, restricted exports to many countries that Bulgaria had previously supplied, some of which came under the United Nations (UN) embargoes. Thirdly, some of Bulgaria's traditional clients developed their basic production capabilities, reducing their need for imports. Fourthly, most arms' importers, especially those from former communist countries, shifted demand to weapons produced to NATO standards, thus reducing the demand for old Soviet-style weaponry (CSD 2004, 'Weapons under scrutiny' report, pp 9-10). For Bulgarian defence industry a new way had to be found out of the frameworks of COMECON and WP- on the world defence market.

In the years of transition to a market economy Bulgaria has undergone a massive deindustrialization losing some of its most sophisticated industries, accordingly severely deteriorating its position in the international division of labour (Zhelev, 2013). After 1989, the MIC underwent widespread structural reforms that reorganized its branch structure, reduced production, stopped technological upgrades and brought the reconstruction and modernization of companies' plants to a virtual halt. In the early 1990s, the management and the large bureaucracy of the defence companies still carried the mentality of the command-administrative economy. There was a need for a new business culture and a new type of relationship with the state, as the MIC was still state-owned. The state did not succeed in formulating a consistent defence industry policy or guidance for long-term development. Reforms were often simply imposed or took shape on an ad hoc basis, in response to severe crises within the industry (CSD 2004, p.19).

After 1989 the production of the enterprises part of BMIC was sharply reduced, the technology renovations were also stopped. There were no possibilities for reconstruction and modernization of the assets available. Bulgarian governments failed in their efforts for the elaboration of defence-industrial policy, nor succeed to draw a long-term plan for the whole industry development as a whole. In its way of transition to a market economy, the Bulgarian industry failed in deep crises with lots of dimensions - structural, market, resources, lack of human resources, finance and lack of technologies.

The processes of demonopolization and decentralization teared up the existing technological relations between the enterprises. As a result, many of them dropped out of the BMIC by reasons of bankruptcy, liquidation and privatization, corruption, buying out with the intent to close the entity and product line changes.

In the process of restructuring the existing BMIC, the systemic relations between the participants in that system were destroyed. In those days the collapse of the system was predetermined by external factors and tendencies in the world defence market on one side and from the slow and inadequate transition to a market economy in Bulgaria, on the other side.

The export from BMIC has begun to drop. The new political conditions restricted the access to the needed technologies which had been received in the past from the former USSR or indirectly from the West. In the existing new competitive conditions, the lack of technologies made the situation impossible for BMIC to create and sell market demanded products. The problem of intellectual property was never solved properly. Especially the relations with the Russian Federation have not been settled. The total crisis in Bulgaria did not enable new technologies to be nationally developed or bought from abroad.

At the entrance of BMIC as a system, basic resources along with the needed technologies and the former markets were no more available. In the new market-driven conditions most of the 
enterprises missed devising their own production and market policy. The end was inevitable - a systemic crisis of BDTIB. The crisis found its expression in the system falling apart. The resources available like personnel and means of production were on a world level. But the lack of the other internal resources which were needed for a self-organized saving of the system has prevailed. The external conditions did not allow product realization - the most important markets have been lost. The entrance of the system was closed - no earnings, no resources available. The system BMIC had not had the option to achieve its goals. Because of the lack of new products at the exit and some internal conflicts in the system (economic, social, political and managerial), the BMIC stopped to exist.

Privatization through employee/management buyouts has not contributed to companies' development (CSD 2004, p.11). Some companies remained in a poor state, with limited access to fresh capital, unable to invest in new technologies and lacking marketing, trade, logistics and business planning skills. Several conversion programs have been developed during the transition to a free market economy, but they have had minimal or no impact. The conversion has been left to the companies' management rather than pursued purposefully by the government. There were no investments for restructuring and/or conversion, nor tax incentives or subsidies.

In general terms, the global tendencies and processes in conjunction with the local ones in Bulgaria predetermined the present state of the Bulgarian defence enterprises and their transformation in BDTIB.

\section{THE PRESENT PROBLEMS AHEAD BDTIB}

Nowadays most of the outlined problems of the Bulgarian enterprises part of BDTIB are unsolved. The financial, human resources and managerial ones prevail over the others.

In 2004 the leading enterprises in BDTIB created a Bulgarian defence industry association $(\mathrm{BDIA})^{4}$. In the framework of the association, there are lots of initiatives for decision consolidating of the problems already outlined.

The participation of the Bulgarian state in seeking decisions of the problems concerned is limited to its support and regulatory role in the economic activities on its territory. In this case, the roles of the Bulgarian Ministry of Defence $(\mathrm{MoD})$ and the Ministry of Economy are to provide institutional support to different activities that aim to promote the capabilities of the BDTIB. The formula for industry participation in the processes of modernization of Bulgarian armed forces (BAF) is still not elaborated. Armed Forces Modernization Plan is more than ten years on the run, and the relevant participation of Bulgarian industry in its implementation is still uncertain. In the principal documents on national security and defence, the role of the Bulgarian defence industry is hardly mentioned at all. A positive step in this direction is the six-year work of the so-called "Industrial Forum" (https://iforum-bg.mod.bg/). It is a platform for practical interaction and cooperation between the public administration, industry and defence and security research and educational organizations in Bulgaria.

Maybe-because of the wish of BDIA with still unelaborated administrative mechanisms to take part in the modernization, regardless of the principle the army supplies to be done in the most cost-efficient way. The Bulgarian producers tend to do anything possible to guarantee their

$4 \quad$ Information for the participants in BDIA could be found at the association website: http://www.bdia-bg.com 
monopoly in specific defence supplies to BAF. In its strategic documents, available only in the Bulgarian language on the BDIA website, the association even goes too far as to suggest, in cases when enterprises take part as main subcontractors in some modernization projects, to be able to deliver and support products and services independently of the main contractor.

The impression created is that BDIA strives for gaining access to BAF modernization projects resources by all means. Maybe part of the Bulgarian enterprises, which could be involved in those projects as subcontractors, see them as one possible way to gain technologies from some of the prime contractors.

In 2012 a Strategy for development of BDTIB was adopted. The strategy represents mainly the viewpoint of BDIA. It would be very difficult for this strategy to be realized. Because of lots of contradictions with the legislation and regulation at the European level. Especially with the ,Defence Package' which included a Communication entitled "Strategy for a stronger and more competitive European defence industry" (COM (2007)764 highlighting the need for regulation at European level, and legislative proposals for two Directives: Directive 2009/43/EC on transfers of defence-related products within the EU; and Directive 2009/81/EC on Defence and Security Procurement.

Till now the implementation of this strategy is not a fact. Only at the end of 2015 a program and a plan for its realization were accepted. Maybe more than five years after this strategy acceptance and in terms of turbulent and dynamic changes in the country and the world it is time for reconsideration. At least it is needed in the area of the strategic goals and the instruments for their achievement.

One other possibility for development is not fully used so far. The participation of the BDTIB in high-tech international projects in NATO's framework is not successful enough. Bulgaria's participation in NATO does not mean direct access to the corresponding markets. At the present time, there are no considerable effects for Bulgaria and its enterprises due to lack of capacity or just interests from Bulgarian side.

\section{THE DRIVING FORCES, KEY FACTORS FOR SUCCESS AND CHALLENGES CONFRONTING THE BDTIB}

BDTIB is still predominately a traditional producer of SALW. This is an increasingly competitive market, characterized by heavy dependence on the existence of regional conflicts. Mainly the conflicts in the Middle East and some other local conflicts (in Ukraine, Nigeria, Algeria, Yemen, Afghanistan etc.) are the engines of the increasing export of defence production from Bulgaria. As stated in a Rand Corporation Europe Report for the European Defence Agency (2016, p.6) the sector is active in exports to non-EU markets, including Afghanistan, Algeria, India and Iraq. At the same time, Bulgaria is looking to expand its arms exports to China and Vietnam. The defence output and export trends are hard to analyze in detail since the information for most of them is classified. Revealing information on the arms production and trade that does not jeopardize the financial situation of the companies is not a common practice in Bulgaria.

At the traditional "Hemus" International Defence Equipment and Services Exhibition (held in the city of Plovdiv every other May) in 2016, it was announced by the Deputy-minister of Econ-

\footnotetext{
https://www.hemusbg.org/en
} 
omy that the country's exports of ammunition and military equipment totaled EUR 235 million for 2013. For 2014 the export totaled EUR 403 million. The expectations for 2015 export are estimated to EUR 642 million. The tendency in SALW is to produce and export ammunition rather than small arms (Milev, 2016).

As can be seen in the table below, export trends for 2015 and the following years remain steadily upward.

Table 1. Export trends - BDITB

\begin{tabular}{|c|c|c|c|c|c|c|}
\hline & $\mathbf{2 0 1 3}$ & $\mathbf{2 0 1 4}$ & $\mathbf{2 0 1 5}$ & $\mathbf{2 0 1 6}$ & $\mathbf{2 0 1 7}$ & $\mathbf{2 0 1 8}$ \\
\hline $\begin{array}{c}\text { Export } \\
\text { (MEUR) }\end{array}$ & 235 & 403 & 642 & 1,015 & 1,219 & 764,54 \\
\hline
\end{tabular}

Note: The total value of permitted transactions of defence-related products for 2018 is more than EUR 1 billion, but part of them are realized in the year 2019.

Source: Annual reports - Interministerial Commission for Export Control and Non-Proliferation of Weapons of Mass Destruction ${ }^{6}, 2013-2019$

The main exported products continue to be classic ammunition, fuses, bombs, rockets, missiles and torpedoes. Much smaller volumes include small arms and light weapons as well as large weapons (weapon systems).

The key factors for this, according to the author temporary success are:

- Along with the good market situation finding the right intermediaries on the ground in the countries end-users of the production is crucial. For this reason, from the available information from the reports of the Interdepartmental Council on Defence Industry and Security of Supply ${ }^{7}$, it is clear that the main export outputs are not from the members of BDIA. At the same time as it could be seen at their website (https://bdia-bg.com/activities/facts-and-figures ) the members of the Association, produce and realize on the national and international markets more than $90 \%$ of the defence production produced in the country (for instance in value terms, only for defence-related products over 1096 878248 euro, which represents 90\% from 1218753609 euros for 2017).

- Another success factor is the supply of adequate products for Russian (Soviet) systems of weapons and equipment, which are widely used in areas of hot conflicts.

- Significant added value brings the fact that many Bulgarian companies implement an active and flexible marketing policy in dealing with customers at their traditional and new markets.

- The recognized quality of Bulgarian products by its consumers is another key factor for success. Alignment with the market situation alone in the absence of clearly defined and followed strategic moves cannot lead to long-term success.

According to Zhelev (2017) after the global crisis it was realized that manufacturing should be assigned a major role for Europe to continue to be a global player. The European Commission has called on EU countries to step up their industrial policies and try to restore the central position of manufacturing for creating jobs and growth. As a member from the Republic of Bulgaria in the AeroSpace and Defence Industries Association of Europe (with 843, 400 workers and 220 bln. Euro for 2017) BDIA could help this process EU and at the national level.

\footnotetext{
6 https://mi.government.bg/en/themes/interministerial-commission-for-export-control-and-non-proliferation-of-weapons-of-mass-destruction-198-338.html http://www.micmrc.government.bg/
} 
The main challenge for BDITB is to become a generator of economic and social security in the country. The results of BDITB's activities in recent years have contributed indirectly to Bulgaria's national security. The contribution can be defined in two directions. On the one hand, is the realization of highly-efficient export within the framework of the overall export of the country. On the other hand, the enterprises in the sector create significant employment in different regions of the country mainly outside the capital city - Sofia. The largest industrial enterprises in the country are part of BDTIB. More than 30,000 employees work in companies that are part of BDTIB. They together with their partners and subcontractors represent over 70,000 employees forming the basis of the socio-economic structure of BDTIB. The long-term success of that industrial sector could not be possible without consolidated state-enterprise policy grounded on uninterrupted technological, market, scientific development and innovation.

\section{CONCLUSION}

Long term success of BDTIB is possible if all actors become aware that the present situation on the markets could not continue in the long run. The possibilities for sustainable dynamic development of that industry could be created only on the base of consolidated state policy grounded on uninterrupted technological, market, scientific development and innovation. The strategic partnerships with leading enterprises and consortiums - suppliers of equipment and services for NATO and EU countries, are the most possible decisions for guaranteeing longterm competitiveness of BDTIB. That is the way for enhancing the innovations, the product and technology modernization. Unfortunately, the absence of adequate strategy and adequate industrial policy and no priorities on a national level in Bulgaria are serious obstacles. In such a situation it would be very hard for BDTIB to enter in target market niches, to develop superior specialization and adequate capabilities or to take part in BAF modernization process. What is more - the problems noted in 2004 (CSD, p.22) are more serious nowadays. Most of the enterprises still have limited access to financing and are not able to invest in new technologies, and are thus compelled to rely on old products. The state has distanced itself from research and development (R\&D). Human resources in the research field are in constant decline due to low pay, better opportunities in other industries, or better offers from the defence sectors of other countries. This leads to a permanent decline in the defence industry's R\&D, and dependency on SALW production and export, which involves less technological sophistication. The arms trade (as the main result from the activities of BDTIB) is dependent on both the political framework reflected in the national defence-industrial policy and the capabilities of the defence companies. Unfortunately, there is no such policy, created and implemented in Bulgaria. The role of the Industry as a whole in the BAF modernization process also has not been determined yet. BDTIB is heavily dependent on the national economy and the modernization process of the BAF.

\section{ACKNOWLEDGEMENT}

This research was supported by the University of National and world economy - Sofia, Bulgaria [Project № NID NI-18/2018 "Development of the Industry in Bulgaria after 1989: Economic, Social and Political effects] and the Institute for Study of Conflicts, Bulgaria. 


\section{REFERENCES}

Brauer, J., \& van Tuyil, H. (1996). Division of Labor in the Non-Soviet Warsaw Pact Arms Industry: 1945-89. In F. J. Chatterji M. (Ed.), Arms Spending, Development and Security (pp. 115-135). New Delhi: Ashish Publishing House.

Center for Study of Democracy (CSD). (2004). 'Weapons under Scrutiny: Implementing Arms Export Controls and Combating Small Arms Proliferation in Bulgaria', Sofia. ISBN 954477-117-4.

Communication from the Commission to the European Parliament, the Council, the European Economic and Social Committee and the Committee of the Regions (2007). A strategy for a stronger and more competitive European Defense Industry. \{SEC(2007) 1596\} \{SEC(2007) 1597\}. Brussels. Retrieved April 11, 2019, from http://eur-lex.europa.eu/legal-content/en/TXT/?uri=CELEX\%3A52007DC0764

Dimitrov, D. (2002). The Restructuring and Conversion of the Bulgarian Defense Industry during the Transition Period. Bonn: Bonn International Center for Conversion. Retrieved April 11, 2019, from https://www.bicc.de/uploads/tx_bicctools/paper22.pdf

Dimitrov, D., \& Ivanov, T. (1993). Problems of National Defense Economy at the end of the 1980 s and beginning of the 1990s. Sofia: University Publishing House 'Stopanstvo'.

Directive 2009/43/EC. (2009, May 6). Directive 2009/43/EC. Directive 2009/43/EC of the European parliament and of the Council simplifying terms and conditions of transfers of defense-related products within the Community. European parliament and the European Council. Retrieved 05 19, 2019, from http://eur-lex.europa.eu/LexUriServ/LexUriServ.do?

Directive 2009/81/EC. (2009, July 13). Directive 2009/81/EC. Directive 2009/81/EC of the European Parliament and of the Council on the coordination of procedures for the award of certain works contracts, supply contracts and service contracts by contracting authorities or entities in the fields of defence. Brussels: European Parliament and of the European Council. Retrieved May 26, 2019, from http://eur-lex.europa.eu/legal-content/EN/ TXT/?uri=celex:32009L0081

Ivanov, T. (1998). Defense Economics and Security Policy of Bulgaria in the Mid-1990s. Sofia: "St. George the Victorious" Publishing house.

Milev, M. (2016, June 26). Where do the Bulgarian weapons go? Capital newspaper. Retrieved October 25, 2019, from http://www.capital.bg/politika_i_ikonomika/bulgaria/2016/06/26/2783493_kude_otiva_bulgarskoto_orujie

Own-initiative opinion of the European Economic and Social Committee. (2012). 'Need for a European defense industry: industrial, innovative and social aspects'. (Official Journal of the European Union 2012/C 299/04). European Economic and Social Committee. Retrieved 11 23, 2019, from http://eur-lex.europa.eu/legal-content/EN/TXT/HTML/?uri=CELEX:52012IE1590\&from $=\mathrm{BG}$

Press release of the European Commission. (2017). A European Defense Fund: 65.5 billion per year to boost Europe's defense capabilities. Retrieved June 19, 2019, from http://europa.eu/ rapid/press-release_IP-17-1508_en.htm

RAND Europe. (2016). Central and Eastern European countries: measures to enhance balanced defense industry in Europe and to address barriers to defense cooperation across Europe. Brussels: European Defense Agency. Retrieved April 11, 2019, Available at: https://www.eda.europa.eu/docs/default-source/documents/rr-1459-eda-central-and-eastern-europe-report---technical-annex---final.pdf

State of the Union Address. (2016). State of the Union Address. Towards a better Europe a Europe that protects, empowers and defends-Speech of the President Juncker. The 
European Commission. Retrieved August 25, 2019, from http://europa.eu/rapid/press-release_SPEECH-16-3043_en.htm

Strategy for the European Defense Technological and Industrial Base. (2007). European Defense Agency. Retrieved September 29, 2019, from https://www.eda.europa.eu/docs/documents/strategy_for_the_european_defense_technological_and_industrial_base.pdf

Zhelev, P. (2013). Industrial Growth - an Objective Necessity for the Economic Development of Bulgaria. In I. Kikerkova (Ed.), Systemic Economic Crisis: Current Issues and Perspectives (pp. 101-114). Skopje: Ss. Cyril and Methodius University, Skopje.

Zhelev, P. (2017). Structural Transformation and Industrial Competitiveness of Bulgaria after 10 Years of EU Membership. Godishnik na UNSS (Issue 1), 87-103. Retrieved from http://unwe-yearbook.org/uploads/Yearbook/Yearbook_2017_No7_\%D0\%9F\%D0\%B0\%D1\%81\% D0\%BA\%D0\%B0\%D0\%BB\%20\%D0\%96\%D0\%B5\%D0\%BB\%D0\%B5\%D0\%B2.pdf 